\title{
THE INTERTEXTUAL USE OF GREEK MYTHOLOGY IN AGATHA CHRISTIE'S DETECTIVE FICTION
}

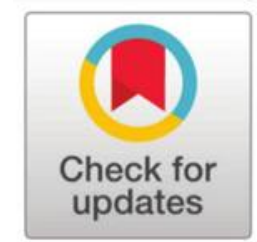

\author{
Tatiana V. Ternopol \\ K.D. Ushinsky Yaroslavl State Pedagogical University, Yaroslavl, Russia
}

\begin{abstract}
This study investigates the intertextual use of Greek mythology in Agatha Christie's short stories Philomel Cottage, The Face of Helen, and The Oracle at Delphi, a short story collection The Labours of Hercules, and a novel, Nemesis. The results of this research based on the hermeneutical and comparative methods reveal that A. Christie's intertextual formula developed over time. In her early works, allusions were based on characters' appearances and functions as well as on the use of motifs and themes from Greek myths. Later on, she turned to using allusory character names; this would mislead her readers who thought they already knew the formula of her stories. Although not a postmodern writer, A. Christie enjoyed playing games of allusion with her readers. She wanted them not only to solve a case but also to discover and interpret the intertextual references.
\end{abstract}

Keywords: detective fiction, intertextuality, hypotext, allusion, intertext, Greek myths, Agatha Christie

\section{Article history:}

Received: 23 June 2020;

Reviewed: 30 June 2019;

Revised: 21 July 2020;

Accepted: 3 August 2020;

Published: 21 December 2020

Copyright (C) 2020 Tatiana Vyacheslavovna Ternopol

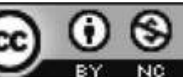

This open access article is published and distributed under a CC BY-NC 4.0 International License which permits non-commercial use, distribution, and reproduction in any medium, provided the original author and source are credited. Permissions beyond the scope of this license may be available at ternopoldp@mail.ru. If you want to use the work commercially, you must first get the authors' permission.

Citation: Ternopol, T. V. (2020). The Intertextual Use of Greek Mythology in Agatha Christie's Detective Fiction. English Studies at NBU, 6(2), 321-331. https://doi.org/10.33919/esnbu.20.2.8

Tatiana Ternopol, $\mathrm{PhD}$ in Cultural Anthropology, is an Associate Professor at the English Language Department of K. D. Ushinsky Yaroslavl State Pedagogical University, Russia where she teaches English literature to students of English Philology.

E-mail: ternopoldp@mail.ru

http://orcid.org/0000-0002-8798-1723 


\section{Background and aims}

Agatha Christie is the best-selling novelist of all time. There is a wealth of scholarly and popular research on her life and works. Her detective novels and short stories have long been considered as belonging to pop culture balanced on the edge of literature and sub-literature. Subsequently, many authors focus on her personal life and her mysterious disappearance between 3 and 14 December1926 (e.g. Morgan, 1985; McCall, 2001; Cade, 2011 etc.) rather than the merits of her literary work.

Scholarly research of her fiction revolves around the following issues: A. Christie's role in the history of detective novel (Knight, 2004); composition and style of her books (Lovitt, 1990; Alexander, 2009); screen adaptations (Aldridge, 2016); gender approach (Makinen, 2006); translation of A. Christie's works (Hudácskó, 2016; Dash, 1975); the use of poisons in her novels (Molin, 2010; Gerald, 2010).

Intertext and intertextuality in Christie's fiction have attracted less academic attention. For example, Makinen (2016) and Hamblen (2014) investigate the influence on A. Christie of British and American writers respectively. Rowland (2010) analyzes the use of Breton legends in her writing and concludes that all detective fiction is essentially mythical. Berger (2015) describes the creation of Hercule Poirot by Agatha Christie as probably the most important popular culture adaptation of the myth of Hercules. Margaret (2012) unveils the intertext of the Greek mythology in The Labours of Hercules. Jackson (2015) examines some of the classical allusions Christie makes in her work, specifically in her Miss Marple novels, including Nemesis. Book reviews by bloggers such as Margaret and Jackson lack deep philological analysis of Christie's texts and are based mainly on their personal attitude towards detective stories. Zavyalova (2014, 2017) looks at the sources of intertextuality in Russian and English detective stories such as Greek and Roman mythology, the Bible etc.; however, in her analysis of Christie's works she focuses on allusions based on nursery rhymes and Shakespeare's tragedies.

The aim of this paper based on hermeneutical and comparative methods is to contribute to the study of the intertextual use of Greek mythology in Agatha Christie's fiction and discover her formula for the use of ancient allusions. The very names of the works we will look at in this paper bear allusions to Greek mythology, i.e. short stories 
The Face of Helen (1930), The Oracle at Delphi (1934) and Philomel Cottage (1948), a short story collection, The Labours of Hercules (1947) and a novel, Nemesis (1971).

\section{Greek mythology in Christie's short stories}

According to her Autobiography, Agatha Christie was home-schooled by her parents and showed a deep interest in reading from an early age (Christie, 1977). She was an avid reader of Greek mythology and ancient literature. However, it was not until mid-1920s that Greek mythology found its way into her own books. The very title of Philomel Cottage, a short story published in 1924, has a loose allusion to the story of Philomela and Procne. Later on, Agatha Christie frequently used titles drawn from literature and folklore. The titles of her mythology-based stories usually feature names of Greek heroes and gods in a search for analogies between these mythical characters and common people depicted in her books.

Of course, she was not unique in turning to Greek mythology for inspiration. In James Joyce's Ulysses (1924), an ordinary Jew from Dublin is compared to Odysseus. Many writers of first half of the twentieth century were in one way or another influenced by this book. Though A. Christie was not a modernist writer, she did use certain modernistic literary techniques (e.g. stream of consciousness in And Then There Were None). Her books based on ancient allusions can be divided into two groups, i.e. earlier writings (short stories, Philomel Cottage, The Face of Helen, The Oracle at Delphi and a collection of short stories, Labours of Hercules, all written and published between 1924-1947) and a mature novel, Nemesis (1971).

The earlier works are less dramatic; the crimes are not serious (stealing, blackmail) or even prevented by a private detective. All of them have a happy ending. If somebody has to die, it is a criminal who deserves this fate. Agatha Christie seems to be a little ironic in her attitude towards her characters that she compares to heroes of Greek mythology. Her description of Hercule Poirot is a brilliant example of this irony,

Here, then, was a modern Hercules - very distinct from that unpleasant sketch of a naked figure with bulging muscles, brandishing a club. Instead, a small compact figure attired in correct urban wear with a moustache (The Labours of Hercules) 
The comparison between ancient heroes and A. Christie's characters in her earlier stories can be seen in their appearance and functions. A beautiful girl at the theatre reminds Mr. Satterthwaite of Helen of Troy,

'Beauty!' said Mr Satterthwaite to himself. 'There is such a thing. Not charm, nor attraction, nor magnetism, nor any of the things we talk about so glibly - just sheer beauty. The shape of a face, the line of an eyebrow, the curve of a jaw. He quoted softly under his breath: 'The face that launched a thousand ships.' And for the first time he realized the meaning of those words.' (The Face of Helen)

Miss Jillian West is described without any irony and her beauty (as Helen's) is her curse. The ability of common people to resemble Greek heroes is also observed by Hercule Poirot; he describes Ted Williamson, a garage mechanic as 'a simple young man with the outward semblance of a Greek god... a Greek god - a young shepherd in Arcady' (Christie, 1947).

In the other stories the characters' appearance usually has some peculiar features that are associated with a certain mythological hero. It is especially clear in "The Labours of Hercules" where humans share some features with the chthonic monsters slain or captured by Hercules. For example, a girl's hair was 'like gold - it went up each side like wings - and she had a gay kind of way of tripping along' (Christie, 1947). The girl was reminiscent of the Ceryneian Hind with its golden antlers and she had even danced a part of a Hind in some ballet performances. A young naval officer is 'tall, magnificently proportioned, with a terrific chest and shoulders, and a tawny head of hair. There was a tremendous air of strength and virility about him....' (Christie, 1947). Hercule Poirot could not but compare him to 'the young Bull - yes, one might say the Bull dedicated to Poseidon' (Christie, 1947) as the Cretan Bull had been.

Sometimes characters are not so pleasant looking. For example, two women met by a young politician Harold Waring by Lake Stempka 'had long, curved noses, like birds, and their faces, which were curiously alike, were quite immobile. Over their shoulders they wore loose cloaks that flapped in the wind like the wings of two big birds' (Christie, 1947). The lake was not Lake Stymphalion, but its name was as significant as the women's appearance so the character considered them an ill omen. 
Humans are not the only one to be compared to the chthonic monsters. Sometimes, Christie is even more ironic and the awful beasts of Greek mythology become nice pets. Dogs represent both the Nemean Lion and Cerberus: a tiny Pekinese and a huge black hound. The last one was so loyal and obedient that its master used it to carry sealed packets of cocaine.

Thus, it is obvious that Christie's characters not only resemble their ancient prototypes outwardly but also share their characters and perform functions associated with them. Her Cerberus guarded the door of a fashionable nightclub Hell situated in a basement. Every visitor had to give it a treat to be able to enter. In The Apples of Hesperides, Hercule Poirot used a man named Atlas to steal a gold goblet decorated with emerald apples. Atlas helped him to break into the convent by offering his back to climb the wall. Here A. Christie combines two main functions of mythological Atlas: he holds the celestial heavens on his back and steals the golden apples from the garden of Hesperides for Hercules.

In Trojan myths, Helen of Troy is a synonym of a woman whose charms are irresistible and cause trouble to men. In The Face of Helen, the main character has a lot of "unpleasantness":

Between them, Mr. Satterthwaite became enlightened as to various happenings which were vaguely classed by Burns under the heading of unpleasantness. "A young man who had shot himself, the extraordinary conduct of a Bank Manager (who was a married man!) a violent stranger (who must have been balmy!) the wild behaviour of an elderly artist. A trail of violence and tragedy that Gillian West had left in her wake, recited in the commonplace tones of Charles Burns. (Christie, 2010).

However, Christie's approach to allusions connected with mythological functions was not the same in all her works. She frequently used mythological allusions to deceive her readers trying to solve the case. Some of her characters associated with the chthonic monsters in The Labours of Hercules because of their appearance are harmless creatures. For example, the two ugly-looking sisters in The Stymphalion Birds never thought of anything connected with crimes, but the main character (and readers as well) accuse them of blackmail. Sometimes a character is referred to mythological characters on purpose to make the other characters believe he or she can perform 
certain functions. In The Oracle at Delphi, Mrs. Peters whose son had been kidnapped turned for help to a person who had advertised himself as a new oracle. He said he could give people advice to solve their problems. In fact, the oracle was the criminal who had organized the kidnapping.

Allusions to appearance and functions of mythological characters are not the only one used by the author. In several stories, she employed the whole plot of a certain myth. To trace the beautiful lady's maid Nita, Hercule Poirot had to travel across Europe similar to Hercules chasing the Ceryneian Hind all over Greece. The use of a mythological plot can also be found in the Cretan Bull, The Apples of Hesperides and The Capture of Cerberus. Employing the whole plot is a peculiar feature of the stories in The Labours of Hercules. However, it is clear that Agatha Christie started by using not the plots but recognizable motifs. A fight between two suitors in The Face of Helen instantly reminds readers of Menelaus and Paris. Later, the girl in the story broke up with her boyfriend and was engaged to a new one associated with Paris and Helen's elopement. Nevertheless, it did not lead to a war between the young men (Christie did not use the plot of the myth).

In Philomel Cottage, the writer adapts a less popular myth about two sisters, Philomel and Procne. Procne's husband Tereus raped and mutilated Philomel and kept her imprisoned in a hut in the wood. She made a beautiful carpet depicting her story and sent it to her sister. In revenge, Procne killed Tereus' son Itis (Takho-Godi, 1982, p. 337). Christie employs several motifs from the myth, i.e. an abusive husband (Alix Martin's husband killed several women whom he had married for money); imprisonment and abuse of a woman (the husband hid the main character in a distant cottage and was preparing to get rid of her); a smart plan worked out by the victim (Alix managed to warn her ex-boyfriend who rescued her); a revenge (the criminal died of fear because he thought Alix had poisoned him).

As for The Oracle at Delphi, the only motif from Greek mythology Christie used was connected with the main function of the ancient oracle: he gave useful advice in any difficult situation.

If we consider the chronological order of the short stories, it is obvious that Christie started by using certain motifs from Greek mythology and ended up using the 
plots in The Labours of Hercules. In the short-story collection, she also applied a metaphoric approach to plots and characters. The Lerneaen Hydra became a metaphor of gossips few people can fight with; the Augean Stables in a need of cleaning represented a political scandal. Hercule Poirot came up with a clever scheme first to ruin and then to clear the reputation of the Prime Minister's wife just as Hercules proceeded with the Augean Stables.

Christie's formula of using Greek myths in her earlier works is represented by the titles and the allusions to the appearance of the characters, their functions, plots and motifs of myths. Sometimes she treats Greek myths as metaphoric stories of people's flaws and sins. Nevertheless, she does not seem to take her stories seriously. Her intention is to make her readers smile comparing the situations in the stories to the myths they studied in school.

\section{Greek mythology in Nemesis}

In her later works, Christie turned to folklore and literary allusions and did not return to Greek mythology until 1970s in her last novel about Miss Marple. The book is entitled Nemesis in line with the author's intention to clearly point to the hypotext she uses. However, it is not only twenty years which separate the novel from her earlier short stories. The formula she uses is new.

First, there are no well-known stories about Nemesis in the Greek mythology. She was honoured as a goddess of retribution and sometimes named the mother of Helen of Troy, but there were no myths directly associated with her (Takho-Godi, 1982, p. 209). There were not any notable features in her appearance except for the wings, according to Mesomedes (Mesomedes, 2011). She was kin to Clotho, Lachesis and Atropos, the Moirai who span the thread of life for every mortal and it was Atropos who cut it. Greeks considered them to be sisters and usually portrayed them as white-robed old women (Losev, 1982, p. 169).

In Nemesis, allusions to the mythological creatures are clear, because Miss Marple was named Nemesis by a late millionaire Jason Rafiel who wanted her to solve the case of an old murder. The main suspects are three elderly sisters with remarkable names: Clotilde (the eldest), Lavinia and Anthea (the youngest). The names are allusions to the Moirai, as well as the fact that they are sisters and live together. Clotilde 
reminded Miss Marple of Clytemnestra while Anthea brings to mind allusions of Ophelia:

She could be cast successfully as a mature Ophelia, Miss Marple thought. Clotilde, Miss Marple thought, was certainly no Ophelia, but she would have made a magnificent Clytemnestra she could have stabbed a husband in his bath with exultation. (Christie, 1971)

Christie tries out a new technique of creating allusions to mythological heroes by giving her characters speaking names, although not as obvious as Hercule or Atlas in The Labours of Hercules. At the same time, the character's appearance becomes less significant; Miss Marple and the Bradbury-Scotts are described as elderly women without any peculiarities of their prototypes.

As for the functions, Miss Marple lived up to the role of Nemesis. She strictly followed Mr. Rafiel's plan to solve the case and the criminal who had killed three women and tried to kill Miss Marple committed suicide. The innocent man was acquitted.

The three Bradbury-Scott sisters did not perform the Moirai's functions for they were not fond of spinning or doing any needlework (it was Miss Marple who enjoyed knitting), but one of them was definitely guilty of several murders, and it was Miss Marple's job to expose her.

In the novel, Christie did not use the plot of any Greek myth; in fact, the tragic story of Verity Hunt and Michael Rafiel was based on Romeo and Juliet with Miss Temple as the Nurse and Archdeacon Brabazon as Friar Lorenzo. The images of ancient goddesses and heroes were used to mislead the readers into searching for allusions to the Greek mythology.

After learning Verity's story (Chapter 10), Miss Marple grew suspicious that at least one of the sisters should know something about the murders and by Chapter 15 she was sure that either Clotilde or Anthea was responsible for the crimes. Lavinia was away with her husband when Verity was killed. At this point, the evidence was against Anthea who was mentally unstable and represented Antropos, the Moira who cut the thread of life and chose the manner of a person's death. The allusion suggested that Anthea was guilty, but in fact it was Clotilde who constantly reminded Miss Marple of Clytemnestra, a 
cruel murderer of her husband. Readers knowledgeable of the Greek mythology will also remember that the Moira responsible for cutting the thread was the eldest of the sisters.

Thus, the technique of using the hypotext of Greek myths in Nemesis is different from the earlier approach. The plot is tragic because of three murders and a long imprisonment of an innocent person. The mood of the text is gloomy as most of the characters are elderly and lonely people. There is no place for irony so common in the earlier short stories. Christie continued using allusions in titles with reference to certain functions of the characters' prototypes and motifs but refrains from employing mythological plots. A new technique was to use speaking names, i.e. allusions to her characters' mythological prototypes, thus misleading the readers who tried to solve the case searching for allusions to the Greek mythology.

\section{Conclusion}

The results of this research based on the hermeneutical and comparative methods reveal that A. Christie's intertextual formula developed over time. In her early works, allusions were based on characters' appearances and functions as well as the use of motifs and themes from the Greek myths. Later on, she turned to using allusory character names. This would mislead her readers who thought they already knew the formula of her stories. Although not a postmodern writer, A. Christie enjoyed playing games of allusion with her readers. She wanted them not only to solve a case but also to discover and interpret the intertextual references.

\section{References}

Aldridge, M. (2016). gatha Christie on Screen. Palgrave Macmillan. https://doi.org/10.1057/978-1-137-37292-5

Alexander, M. (2009). Rhetorical structure and reader manipulation in Agatha Christie's Murder on the Orient Express. Miscelánea: A Journal of English and American Philology, 39, 13-27. http://eprints.gla.ac.uk/32230/1/id32230.pdf

Berger A.A. (2013). Hercules (aka Herakles) and Hercule Poirot. In A. A. Berger. Media, Myth, and Society (pp 90-98). Palgrave. https://doi.org/10.1057/9781137301673 6

Cade, J. (2011). Agatha Christie and the Eleven Missing Days. Revised edition. Peter Owen Publishers. 
Christie A. (1934). The Oracle at Delphi. In Christie A. Parker Pyne Investigates. Collins Mystery. https://royallib.com/read/Christie Agatha/Parker Pyne Investigates.html\#0

Christie A. (1947). The Labours of Hercules. Dodd, Mead \& Co. http://booksonline.com.ua/view.php?book=157951

Christie A. (1971). Nemesis. Collins Crime Club. http://booksonline.com.ua/view.php?book=98843

Christie A. (1977). An Autobiography. Collins.

Christie A. (2010) The Face of Helen. In Christie A. The Mysterious Mr. Quin. HarperCollins. https://libcat.ru/knigi/detektivy-i-trillery/klassicheskijdetektiv/176865-35-agatha-christie-the-mysterious-mr-quin.html\#text

Christie A. (2011). Philomel Cottage. London: HarperCollins. https://litportal.ru/avtory/agata-kristi/read/page/1/kniga-philomel-cottagean-agatha-christie-short-story-841503.html

Dash, F. L. (1975). Miss Marple Goes to Spain. Modern Languages, 56, 177-180.

Gerald, M. (2010). The Poisonous Pen of Agatha Christie. University of Texas Press.

Jackson, K. (2015). Classical Allusions and Miss Marple. https://crossexaminingcrime.wordpress.com/2015/10/20/classical-allusionsand-miss-marple/

Hamblen, A. (2014). The Inheritance of the Meek: Two Novels by Agatha Christie and Henry James. Discourse, XII, 409-413.

Hudácskó, B. (2016) And Then There Were Many: Agatha Christie in Hungarian Translation. In Bernthal J.C (Ed.), The Ageless Agatha Christie: Essays on the Mysteries and the Legacy. McFarland \& Company.

Knight, S. (2004). Crime Fiction 1800-2000: Detection, Death, Diversity. Palgrave Macmillan.

Losev. A. (1982). Moiry. [The Moirai]. In Tokarev S.A. (Ed.), Mify narov mira. [Myths of the World]. (p. 169). Sovetskaya Yenciclopediya.

Lovitt. C. (1990). Controlling Discourse in Detective Fiction: or, Caring Very Much Who Killed Roger Ackroyd. In Walker R. \& Frazer J. (Eds.), The Cunning Craft: Original Essays on Detective Fiction and Contemporary Literary Theory. (pp. 68-85). Western Illinois University.

Makinen, M. (2006). Agatha Christie: Investigating Femininity (Crime Files). Palgrave Macmillan. https://doi.org/10.1057/9780230598270 
Makinen, M. (2016). Agatha Christie in Dialogue with To the Lighthouse: The Modernist Artist. In Bernthal J.C (Ed.), The Ageless Agatha Christie: Essays on the Mysteries and the Legacy. McFarland \& Company.

Margaret (2012). The Labours of Hercules by Agatha Christie: a Book Review.

BooksPlease. A book lover writes about this, that and the other.

https://booksplease.org/2012/03/17/the-labours-of-hercules-by-agatha-

christie-a-book-review

McCall, H. (2001). The Life of Max Mallowan: Archaeology and Agatha Christie. British Museum Press.

Mesomedes (2011) Hymn to Nemesis (Trans. Foreman A.Z.) http://poemsintranslation.blogspot.com/2011/05/mesomedes-hymn-tonemesis-from-greek.html

Molin Ju. A. (2010). Tvorchestvo Agaty Kristi - Medicinskie aspekty (k 120-letiju so dnya rozhdeniya). [Works of Agatha Christie - Medical Aspects (dedicated to her 120 anniversary)]. Medicinskaya ekspertiza i pravo, 6, 49-50.

Morgan, J. (1985). Agatha Christie: A Biography. Fontana/Collins.

Rowland, S. (2010). The Wasteland and the Grail Knight: Myth and Cultural Criticism in Detective Fiction. Clues: A Journal of Detection, 28(2) (Fall), 44-54. https://doi.org/10.3172/CLU.28.2.44

Takho-Godi, A. (1982). Procna. [Procne]. In Tokarev S.A. (Ed.), Mify narov mira. [Myths of the World]. (p. 337). Sovetskaya Yenciclopediya.

Takho-Godi, A. (1982). Nemesida. [Nemesis]. In Tokarev S.A. (Ed.), Mify narov mira. [Myths of the World]. (p. 209). Sovetskaya Yenciclopediya.

Zavyalova, G. (2014). Osobennosti funkcionirovanija precedentnyh fenomenov v detektivnom diskurse (na materiale anglijskogo i russkogo jazykov). Dissertacija na soiskanie uchenoj stepeni kandidata filologicheskih nauk. Kemerovo. [Peculiarities of the functioning of precedent texts in detective fiction (with examples from Russian and English fiction]. [Unpublished doctoral dissertation]. Kemerovo.

Zavyalova, G. (2017). Istochniki precedentnosti v detektivnom diskurse. Vestnik Kemerovskogo gosudarstvennogo universiteta, 2017, 2, 195-199 [Sources of precedent texts in detective fiction. Bulletin of Kemerovo State University]. https://doi.org/10.21603/2078-8975-2017-2-195-199 